\title{
IJBE
}

International Journal of Business Economics, 1(1), 38-48, September 2019

http://jurnal.umsu.ac.id/index.php/ijbe

eISSN 2686-472X

ORIGINAL ARTICLE

\section{Rules Enforcement and Unethical Behavior: Empirical research on Employee Fraud in Local Government Agencies}

\author{
Dekeng Setyo Budiarto*, Yona Setyoningtyas
}

\begin{abstract}
The tendency of fraud is one of the major threats to Indonesian country. The current research aims to study the effect of rules enforcement and unethical behaviors on the tendency of fraud based on gender. The sample consists of 126 employees from 28 Local Government Agencies (LGAs) in Kulon Progo regency. Purposive sampling was the sampling technique employed in this study. The results demonstrated a significant effect of unethical behavior on the tendency of fraud. However, rules enforcement level has no significant effect on the tendency of fraud. In addition, gender differences were observed in unethical behavior and the tendency of fraud. On the other hand, gender differences were not present in the level of rules enforcement.
\end{abstract}

Keywords: Rules enforcement, unethical behavior, tendency of fraud, gender

DOI : https://doi.org/10.30596/ijbe.v1i1.3314

JEL Classification : G00, G41, G53

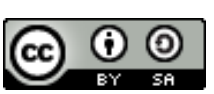

Published by IJBE, Indonesia | Copyright (C) 2019 by the Author(s) | This is an open access article distributed under the Creative Commons Attribution License http://creativecommons.org/licenses/by/4.0), which permitsunrestricted use, distribution, and reproduction in any medium, provided the original work is properly cited.

Cite this article as:

Budiarto, D. S., \& Setyoningtyas, Y. (2019). Rules Enforcement And Unethical Behavior: Empirical research on Employee Fraud in Local Government Agencies. International Journal of Business Economics (IJBE), 1(1), 38-48.

Universitas PGRI Yogyakarta

Jalan IKIP PGRI I Sonosewu No.117, Sonosewu, Ngestiharjo,

Kec. Kasihan, Bantul, Daerah Istimewa Yogyakarta 55182, Indonesia

*Corresponding Author: dekengsb@upy.ac.id 


\section{IJBE}

International Journal of Business Economics, 1(1), 38-48, September 2019

http://jurnal.umsu.ac.id/index.php/ijbe

eISSN 2686-472X

The Audit Board of the Republic Indonesia (BPK RI) revealed in 2018 as many as 15,773 financial problems resulting in a 11.55 trillion Rupiah loss during the inspection process for the first semester of 2018. Some of them include weaknesses of internal control system and noncompliance with the rules resulting in a 10.06 trillion Rupiah loss, as well as inefficiency and ineffectiveness resulting in a 1.49 trillion rupiah loss (bpk.go.id). The problems revealed through BPK's auditing should be dealt with immediately to make the state financial management system increasingly transparent and accountable. One way to improve state financial management is by implementing an effective and efficient internal control system. An internal control system is indispensable for an organization to minimize weaknesses in human resources and to reduce the potential erroneous conducts that violate the rules (Mustika, Hastuti, \& Heriningsih, 2016).

Every person or the perpetrator of fraud has different motivation. A fraudulent act is usually triggered by the desire to present a financial report that involves overstating assets and understating liabilities. In addition, fraudulent acts may occur because of the opportunity to commit them. Fraud constitutes act of deceiving others that includes various deviant and unlawful acts by committing intentional deception (Mustikasari, 2013).

Fraudulent acts are commonplace among government employees and, thereby, adversely affecting public trust. Accountability and transparency are, therefore, needed to restore the public trust. Improvement of the planning and control of activities by improving the accounting system in public sector is expected to help build the transparency and effectiveness in local governments. Improvement of control system will increase effectiveness, especially in providing information and revealing the activities and financial performance of local governments (Santoso \& Pambelum, 2008).

Fraud is an unlawful act committed by parties who have relationships with and interests in an organization. Ineffectiveness of rules enforcement provides chances for organizational insiders and outsiders to commit a breach of agreed upon rules. Fraudulent activities in organizational environment are likely to occur as a consequence of weak enforcement of rules. One of commonplace fraud cases in Indonesia is corruption. Corruption is a fraudulent conduct that involves records and document manipulation, and price marking up that is detrimental to the financial or economy of an organization (Safitri, Hasan, \& Fachrunisa, 2015).

Unethical behavior by an individual might end up causing harm to various parties. An individual with the habit of behaving unethically will increase the likelihood of fraudulent conducts, including tax evasion. Tax evasion is among the worst effects of unethical behavior. It is an unethical behavior because it violates generally accepted moral norms. Unethical behavior in the tax evasion is usually carried out to reduce the tax liability by illegal means, such as counterfeit or forged document, and incomplete or incorrect data entry (Budiarto \& Nurmalisa, 2018).

The present study is more interesting compared to previous ones that generate inconsistent results. Several researches demonstrated that unethical behaviors and rules enforcement have a significant effect on fraud (Ahriati, Basuki, \& Widiastuty, 2016; Mustika et al., 2016; Mustikasari, 2013; Najah, 2013; Rizky \& Fitri, 2017). Other studies showed that unethical behaviors and rules enforcement have no significant effect on fraud (Wilopo, 2008; Wulandari \& Zaky, 2016; Zulkarnain, 2013). This study attempts to explore the relationship between unethical behavior, rules enforcement and fraud from a gender perspective, which has not been adequately conducted thus far. A number of studies described that men and women 


\section{IJBE}

International Journal of Business Economics, 1(1), 38-48, September 2019

http://jurnal.umsu.ac.id/index.php/ijbe

eISSN 2686-472X

may differ with regards to what can be perceived as ethical or unethical behaviors, especially in the workplace (Tang \& Chen, 2008; Westbrook, Steven Arendall, \& Padelford, 2011).

The tendency of fraud is one of the major threats confronting many countries, including Indonesia. In many cases, the tendency of fraud in this country takes the forms of omitting or concealment of actual information that, in the end, misleads the stakeholders. According to the Association of Certified Fraud Examiners (ACFE), fraud is unlawful conduct committed intentionally for certain purposes by organizational insiders or outsiders to secure personal or collective gains, either directly or indirectly, to the detriment of third parties (Tuanakotta, 2007).

Rules enforcement is an activity to counterbalance the relationship between existing values embodied in the principles that serve to elaborate the values to develop, maintain, and preserve the wholeness. All general and specific regulations cover three areas: conducts or behaviors that are required or prohibited; consequences or sanctions that are the responsibility of the offender; the procedures to communicate regulation to the individuals subject to it. Rules designed and implemented in an organization usually contain values that serve as reference for the applicable code of conducts. Effective rules enforcement can reduce the occurrence of fraud in an organization because clear and explicit rules will guarantee the exercise of rights, obligations and responsibilities of each member of the organization. If the regulations in an agency were implemented properly, the tendency of fraud will also decrease (Mustika et al., 2016).

Several researches demonstrated that rules enforcement has a negative effect on the tendency of fraud (Mustikasari, 2013; Najah, 2013). Proper rules enforcement can reduce the tendency of fraud in an organization. From the above description on the researches conducted so far, the following hypothesis can be formulated:

$H_{1}$ : $\quad$ Rules enforcement has a negative effect on the tendency of fraud

Unethical behavior is an action that falls outside of what is considered to be the main task or the agreed upon goals (Ahriati et al., 2016). Fraudulent conduct can be affected by many factors, for example unethical behavior. Unethical behavior can be in the forms of abuse of authority or position, organizational resources, and power, and of not fulfilling the obligation that is supposed to fulfill. It is related to an organization's ethical standard; lower ethical standard may lead to higher level of fraud (Zulkarnain, 2013).

Unethical behavior is an action that falls outside of what is considered to be the main task or the agreed upon goals (Ahriati et al., 2016; Van Dijk, 2000). Among the factors that affect fraud is unethical behavior. There are two main factors that may lead individuals to engage in unethical behavior: (1) ethical standard of an individual may differ from that of the general public; (2) an individual intentionally engages in unethical behavior to secure personal gain (Arifiyani \& Sukirno, 2012). The many needs that remain unfulfilled may force individuals to engage in unethical behavior for the purpose of securing more personal gains. Unethical behavior is largely determined by the interaction between personal characteristics and asocial phenomena that arise from the environment as well as from complex psychological factors.

The results of previous researches indicated that unethical behavior has a positive effect on the tendency of fraud (Ahriati et al., 2016; Zulkarnain, 2013). The higher the level of unethical behavior in an individual, the more likely that he or she will engage in fraudulent conducts. Based on the results of previous researches, the second hypothesis can be formulated as follows:

$\mathrm{H}_{2}$ :Unethical behavior has a positive effect on the tendency of fraud 


\section{IJBE}

International Journal of Business Economics, 1(1), 38-48, September 2019

http://jurnal.umsu.ac.id/index.php/ijbe

eISSN 2686-472X

\section{Gender-Based Analysis}

The term gender denotes the identities of men and women either in biological or nonbiological terms, such as social, psychological and cultural processes (Wankhar \& Diana, 2018). ). Prior researches conducted from a gender perspective indicated women to have higher ethical standards than men. Differences between women and men in ethical standards might be due to differences in men and women's socialization. Men are usually exposed more to a competitive socialization, while women put more emphasis on social relationship (Hafizhah \& Basri, 2016).

Cognitive dissonance theory is frequently used to help describe the effect of gender on decision-making in accounting. This can be seen, among other, from the skepticism of professional auditors that consistently question and evaluate critically the audit evidence before expressing his or her opinion. A prior study demonstrated that female auditors express higher professional skepticism than their male counterparts. This indicated that women still need to be taken into account because of their high conservatism and cautious in decision-making, tend to avoid risks and be more thorough (Kusumastuti, Supatmi, \& Sastra, 2008; Noviyanti, 2008). Based on the results of the above mentioned studies, the hypotheses can be formulated as follows:

$\mathrm{H}_{3 \mathrm{a}}$ : Gender-based differences were found at the levels of rule enforcement.

$\mathrm{H}_{3 \mathrm{~b}}$ : Gender-based differences were found at the levels of unethical behavior.

$\mathrm{H}_{3 c}$ : Gender-based differences were found at the levels of fraud tendency.

\section{RESEARCH METHOD}

The present study employs a quantitative method using primary data gathered through the distribution of questionnaires. The questionnaire consists of a number of questions on fraud tendency, rules enforcement, and unethical behavior. The study used a purposive sampling technique based on a number of criteria which includes: first, financial staff authorized for official accountability reports; second, one year of work experience at minimum; and third, not in a process of being transferred to another agency.

The tendency of fraud serves as the dependent variable in this study. The tendency of fraud is characterized by three indicators: first, financial statement fraud; second, misuse of assets; and third, corruption (Najah, 2013). Measurement of fraud tendency uses 5 point Likert scale from point 1 (strongly agree) to 5 (strongly disagree). The higher the point indicated, the more likely that fraudulent conducts occur.

Rules enforcement serves as independent variable in this study. It is characterized by 5 indicators: first, obedience to law; second, law enforcement process; third, organizational rules; fourth, discipline at work; and fifth, responsibility (Najah, 2013). Rules enforcement is measured using 5-points Likert scale, from 1 (strongly agree) to 5 (strongly disagree). The lower the point indicated, the lower the rules enforcement level in an organization.

Unethical behavior is used as the independent variable in this study. It is characterized by 5 indicators: first, managerial abuse of position; second, managerial abuse of organizational resources; third, managerial abuse of power; fourth, managerial non-action (no action on the part of the management); and fifth, managerial abuse of the rules (Mustika et al., 2016). Unethical behavior is measured using 5 point Likert scale, from point 1 (strongly agree) to point 5 (strongly disagree). The higher the score indicated, the more unethical the behavior will be. 


\section{IJBE}

International Journal of Business Economics, 1(1), 38-48, September 2019

http://jurnal.umsu.ac.id/index.php/ijbe

eISSN 2686-472X

\section{RESULTS AND DISCUSSION}

The sample of this study consisted of 126 employees from 28 Local Government Agencies (LGAs) in Kulon Progo regency. A total of 158 questionnaires were distributed, with a return rate of $88.7 \%$ or 142 questionnaires. The total data processed were 126 questionnaires and data unprocessed were 16 questionnaires for a reason of incomplete responses.

Table 1. Description of Respondents

\begin{tabular}{llcc}
\hline & \multicolumn{1}{c}{ Description } & Total & Percentage \\
\hline Gender & Men & 62 & $49 \%$ \\
& Women & 64 & $51 \%$ \\
\hline Age (years) & $20-30$ & 10 & $7.9 \%$ \\
& $21-40$ & 34 & $26.9 \%$ \\
& $41-50$ & 60 & $47.7 \%$ \\
& $>50$ & 22 & $17.5 \%$ \\
\hline Educational Attainment & SHS or Equivalent & 37 & $29.4 \%$ \\
& D3 (Associate Degree) & 9 & $7.1 \%$ \\
& S1 (Bachelor's Degree) & 69 & $54.8 \%$ \\
& S2 (Master's Degree) & 11 & $8.7 \%$ \\
\hline Position & Finance Staff & 82 & $65.1 \%$ \\
& Divisional Secretary & 3 & $2.4 \%$ \\
& Head of Sub-division & 30 & $23.8 \%$ \\
& Head of Division & 11 & $8.7 \%$ \\
\hline Tenure in Occupation & $<10$ years & 17 & $13.5 \%$ \\
& $10-20$ years & 49 & $38.9 \%$ \\
& $21-30$ years & 53 & $42.1 \%$ \\
& $31-40$ years & 7 & $5.5 \%$ \\
\hline
\end{tabular}

The instruments in this study were tested to determine the validity and reliability. The results indicated that the instrument is valid ( $\mathrm{P}$-value $<0.05)$. Example of validity assessment for the tendency of fraud is shown in Table 2. The results of reliability assessment (Table 3) indicate that all variables used in this study were reliable with the value of Cronbach's alpha greater than 0.07 .

Table 2. The results of instrument validity assessment of fraud tendency

\begin{tabular}{|c|c|c|}
\hline No & Instrument & $\begin{array}{c}\text { Pearson } \\
\text { Correlation }\end{array}$ \\
\hline 1. & It is not uncommon in my agency that, for some reasons, the expenses are overstated. & $0.791^{* *}$ \\
\hline 2. & $\begin{array}{l}\text { It is not a problem for my agency if the proofs of transaction are recorded without notice } \\
\text { to the authorized officer. }\end{array}$ & $0.761^{* *}$ \\
\hline 3. & $\begin{array}{l}\text { It is normal for my agency that, for some reasons, the prices of office equipment and } \\
\text { stationery are overstated. }\end{array}$ & $0.872^{\star *}$ \\
\hline 4. & $\begin{array}{l}\text { It is normal that budget users in my agency included other irrelevant items into office } \\
\text { equipment budget. }\end{array}$ & $0.863^{\star *}$ \\
\hline 5. & It is normal for budget users in my agency to use false invoices for office equipment. & $0.852^{\star \star}$ \\
\hline 6. & $\begin{array}{l}\text { It is not a problem for my agency if the purchased office supplies and equipment do not } \\
\text { comply with the predetermined specifications. }\end{array}$ & $0.852^{* *}$ \\
\hline 7. & It is not a problem for my agency if a transaction has double slips or invoices. & $0.635^{\star *}$ \\
\hline 8. & It is not uncommon to find expenses without any supporting documents in my agency. & $0.829^{\star *}$ \\
\hline 9. & $\begin{array}{l}\text { It is not a problem in my agency if the resulted budget surplus is distributed as bonus } \\
\text { pay to the employees. }\end{array}$ & $0.817^{* *}$ \\
\hline
\end{tabular}




\section{IJBE}

International Journal of Business Economics, 1(1), 38-48, September 2019

http://jurnal.umsu.ac.id/index.php/ijbe

eISSN 2686-472X

Table 3. Results of Reliability Assessment

\begin{tabular}{lccc}
\hline Variable & Item & Cronbach Alpha & Description \\
\hline Rules Enforcement & X1.1-X1.5 & 0,814 & Reliable \\
Unethical Behavior & X2.1-X2.5 & 0,782 & Reliable \\
Tendency of Fraud & Y.1-Y.9 & 0,920 & Reliable \\
\hline
\end{tabular}

Source: Primary data, 2019

Table 4. T-test results (Hypotheses 1 and 2)

\begin{tabular}{llll}
\hline \multicolumn{1}{c}{ Variable } & $\mathrm{B}$ & $P$ value & Result \\
\hline Rules Enforcement & -0.003 & 0.970 & H1: rejected \\
Unethical Behavior & 0.877 & $0.000^{\star *}$ & H2: accepted \\
\hline $\mathrm{F}=45.806$ & & $0.000^{\star *}$ & \\
Adjusted $R^{2}=0.418$ & & &
\end{tabular}

The testing of hypotheses 1 and 2 were conducted to determine the effect of rules enforcement and unethical behavior on the tendency of fraud. The testing of hypothesis 3 was conducted to determine if gender differences were observed in rules enforcement, unethical behavior, and the tendency of fraud.

Table 4 shows that rules enforcement has no effect on fraud tendency, with $\mathrm{p}$ value $>$ $0.05(0.970)$. This result confirmed the findings of previous study suggesting that rules enforcement does not guarantee that fraudulent conducts will not occur in an agency (Rachmanta \& Ikhsan, 2014). ). Some people tend to take the easy way to reach their goals. They want to realize their desires or fulfill their needs in an instant way. This will encourage them to engage in undisciplined conducts and consider violation of rules as normal provided that they can realize what they want. While the rules have been enforced, fraudulent conducts remain to occur (Indriastuti, 2017).

The hypothesis testing in table 4 shows that unethical behavior has an effect on fraud tendency with $\mathrm{p}$-value $<0.05$. The results confirm the finding of previous study that if an employee engaged in unethical behavior, it is highly likely that he or she will commit fraud. On the contrary, ethical behavior on the part of the employees will reduce the chance of fraud in public sector (Ahriati et al., 2016; Zulkarnain, 2013).

Independent sample t-test (Table 5) indicates that no differences were observed between male and female subjects in rules enforcement, with the p value $>0.05$ and, thereby, $\mathrm{H} 3 \mathrm{a}$ is rejected. Unethical behavior has a $\mathrm{p}$ value of $0.013<0.05$, while fraud tendency has a $\mathrm{p}$ value of $0.019<0.05$. It can be concluded, therefore, that there are gender differences in unethical behavior and fraud tendency. Women hold on to higher ethical standard than men. Women are more careful in taking actions and try to avoid risks that might harm them in the long run, in contrast to men who don't think of the long-term consequences when making decisions (Tripermata, 2016).

Table 5 shows no differences between men and women if measurement was conducted using instrument number 4. Male and female respondents stated that they feel that they adhered to the rules in their workplace by going to and leaving their office on time. A prior study found that men and women share a lot of similarities in behaving on the job. This is due to a number of factors such as environment, job demands, and organizational culture that require employees to work professionally and comply with similar ethical standards (Westbrook et al., 2011). 


\section{IJBE}

International Journal of Business Economics, 1(1), 38-48, September 2019

http://jurnal.umsu.ac.id/index.php/ijbe

eISSN 2686-472X

From Table 7 indicates the significance level of the t-test for each instrument for ethical behavior. From the table we see that significance differences were observed in instruments number 3 and 5. Female respondents stated that women in their workplace will take action when there is a disservice. On the contrary, male respondents tend to stay silent when other employees engaged in conducts that can harm the agency. Differences between men and women confirm a prior study suggesting that women hold on to higher ethical standards than men (Tang \& Chen, 2008).

Table 5. Results of independent samples t-test (Hypothesis 3)

\begin{tabular}{cccccc}
\hline Variables & \multicolumn{2}{c}{ Mean } & Lavene's & $P$ value & Results \\
\cline { 2 - 3 } & $\mathrm{M}$ & $\mathrm{F}$ & & & \\
\hline test & & & & \\
Rules Enforcement & 4.316 & 4.147 & 0.244 & 0.066 & H3a: Rejected \\
Unethical Behavior & 4.465 & 4.288 & 0.339 & $0.013^{*}$ & H3b: Accepted \\
Tendency of Fraud & 4.465 & 4.243 & 0.901 & $0.019^{*}$ & H3c: Accepted \\
\hline
\end{tabular}

$*$ Sig $<5 \%$

Table 6. Results of Independent Samples t-Test for Rules Enforcement

\begin{tabular}{|c|c|c|c|c|c|}
\hline \multirow{2}{*}{ No } & \multirow{2}{*}{ Instrument } & \multicolumn{2}{|c|}{ Mean } & \multirow{2}{*}{$\begin{array}{l}\text { Lavene's } \\
\text { test }\end{array}$} & \multirow{2}{*}{$P$ Value } \\
\hline & & $M$ & $F$ & & \\
\hline 1. & $\begin{array}{l}\text { There are rules to adhere to in my agency where I } \\
\text { work. }\end{array}$ & 4.565 & 4.328 & 0.484 & $0.023^{*}$ \\
\hline 2. & $\begin{array}{l}\text { I feel that the officers at my agency where I work } \\
\text { are responsive in rules violation settlement. }\end{array}$ & 4.274 & 4.094 & 0.550 & 0.105 \\
\hline 3. & $\begin{array}{l}\text { In the agency where I work, the operational } \\
\text { activities are carried out in accordance with the } \\
\text { standards and regulations set by the agency and } \\
\text { the government. }\end{array}$ & 4.403 & 4.219 & 0.182 & 0.112 \\
\hline 4. & $\begin{array}{l}\text { In the agency where I work, all employees come } \\
\text { into the office and leave on time. }\end{array}$ & 4.048 & 3.891 & 0.867 & 0.324 \\
\hline 5. & $\begin{array}{l}\text { At the agency where I work, all employees work in } \\
\text { compliance with their respective job descriptions. }\end{array}$ & 4.290 & 4.203 & 0.029 & 0.431 \\
\hline
\end{tabular}

Table 7. Results of independent samples t-test for ethical behavior

\begin{tabular}{|c|c|c|c|c|c|}
\hline \multirow{2}{*}{ No } & \multirow{2}{*}{ Instrument } & \multicolumn{2}{|c|}{ Mean } & \multirow{2}{*}{$\begin{array}{l}\text { Lavene's } \\
\text { test }\end{array}$} & \multirow{2}{*}{$P$ value } \\
\hline & & $M$ & $F$ & & \\
\hline 1. & $\begin{array}{l}\text { In the agency where I work, I have used the office } \\
\text { vehicle for personal errands. }\end{array}$ & 4,194 & 4,031 & 0,106 & 0,114 \\
\hline 2. & $\begin{array}{l}\text { In the agency where I work, I once asked a fellow } \\
\text { employee for a vacation ticket. }\end{array}$ & 4,548 & 4,469 & 0,258 & 0,390 \\
\hline 3. & $\begin{array}{l}\text { In the agency where I work, I stay silent upon } \\
\text { knowing that other employees engaged in } \\
\text { conducts that can harm the agency. }\end{array}$ & 4,355 & 4,125 & 0,017 & $0,011^{*}$ \\
\hline 4. & $\begin{array}{l}\text { In the agency where I work, I have a frequent lack } \\
\text { of attendance for no good reasons. }\end{array}$ & 4,629 & 4,469 & 0,429 & 0,081 \\
\hline 5. & $\begin{array}{l}\text { In the agency where I work, I frequently arrive late } \\
\text { to work without valid excuses. }\end{array}$ & 4,597 & 4,344 & 0,738 & $0,013^{*}$ \\
\hline
\end{tabular}

${ }^{*}$ Sig $<5 \%$ 


\section{IJBE}

International Journal of Business Economics, 1(1), 38-48, September 2019

http://jurnal.umsu.ac.id/index.php/ijbe

eISSN 2686-472X

From Table 8 we see that differences were observed between men and women in questions number 4, 5, 6, 8, and 9. Female respondents disagree if the budget of their agency was spent for purposes other than it is supposed to spend. On the other hand, male respondents stated that it won't be a problem the budget was spent for other organizational purposes considered as complex and urgent. This result confirms the finding of a prior study suggesting that high love-of-money individuals will do everything to meet their needs and desires even if it violates the rules applicable to them (Tripermata, 2016).

Table 8. Results of independent samples t-test for fraud tendency

\begin{tabular}{|c|c|c|c|c|c|}
\hline \multirow{2}{*}{ No } & \multirow{2}{*}{ Instrument } & \multicolumn{2}{|c|}{ Mean } & \multirow{2}{*}{$\begin{array}{l}\text { Lavene's } \\
\text { test }\end{array}$} & \multirow{2}{*}{$P$ value } \\
\hline & & $M$ & $\mathrm{~F}$ & & \\
\hline 1. & $\begin{array}{l}\text { It is not uncommon in my agency that, for some } \\
\text { reasons, the expenses are overstated. }\end{array}$ & 4.403 & 4.188 & 0.296 & 0.101 \\
\hline 2. & $\begin{array}{l}\text { It is not a problem for my agency if the proofs of } \\
\text { transaction are recorded without notice to the } \\
\text { authorized officer. }\end{array}$ & 4.468 & 4.266 & 0.167 & 0.053 \\
\hline 3. & $\begin{array}{l}\text { It is normal for my agency that, for some } \\
\text { reasons, the prices of office equipment and } \\
\text { stationery are overstated. }\end{array}$ & 4.468 & 4.250 & 0.772 & 0.050 \\
\hline 4. & $\begin{array}{l}\text { It is normal that budget users in my agency } \\
\text { included other irrelevant items into office } \\
\text { equipment budget. }\end{array}$ & 4.500 & 4.234 & 0.846 & $0.015^{\star}$ \\
\hline 5. & $\begin{array}{l}\text { It is normal for budget users in my agency to use } \\
\text { false invoices for office equipment. }\end{array}$ & 4.548 & 4.328 & 0.993 & $0.043^{*}$ \\
\hline 6. & $\begin{array}{l}\text { It is not a problem for my agency if the } \\
\text { purchased office supplies and equipment do not } \\
\text { comply with the predetermined specifications. }\end{array}$ & 4.458 & 4.266 & 0.926 & $0.009^{*}$ \\
\hline 7. & $\begin{array}{l}\text { It is not a problem for my agency if a transaction } \\
\text { has double slips or invoices. }\end{array}$ & 4.161 & 4.047 & 0.741 & 0.537 \\
\hline 8. & $\begin{array}{l}\text { It is not uncommon to find expenses without any } \\
\text { supporting documents in my agency. }\end{array}$ & 4.516 & 4.297 & 0.462 & $0.047^{*}$ \\
\hline 9. & $\begin{array}{l}\text { It is not a problem in my agency if the resulted } \\
\text { budget surplus is distributed as bonus pay to the } \\
\text { employees. }\end{array}$ & 4.581 & 4.313 & 0.150 & $0.018^{*}$ \\
\hline
\end{tabular}

\section{CONCLUSION}

From the data analysis described in earlier sections, we have come to the conclusion that unethical behavior has a significant effect on fraud tendency. Rules enforcement, on the other hand, has no significant effect on fraud tendency. In addition, while the results of this study show that gender differences were observed between unethical behavior and fraud tendency, gender differences were not observed in rules enforcement.

The present study uses only two variables that affect the tendency of fraud. For future researches, we suggest the use of additional variables that affect the tendency of fraud such as integrity, because the latter is an impartial moral principle that promotes honesty in an individual (Singgih, Yuliati, \& Amrul, 2018). This study employs only quantitative research questionnaires. We, therefore, recommend that future researches combine the qualitative and quantitative methods. The combined method will collect respondent data through observation and direct interview to generate more accurate results that close to the actual situation (Faisal, 2013). This study remains very limited in both the respondents and the scope. We, therefore, recommend future researches to improve the method, to increase the number of respondent and 


\section{IJBE}

International Journal of Business Economics, 1(1), 38-48, September 2019

http://jurnal.umsu.ac.id/index.php/ijbe

eISSN 2686-472X

to extend the research object in order to obtain more accurate picture and results that are closer to the actual situation (Ahriati et al., 2016).

\section{REFERENCES}

Ahriati, D., Basuki, P., \& Widiastuty, E. (2016). Analisis Pengaruh Sistem Pengendalian Internal, Asimetri Informasi, Perilaku Tidak Etis dan Kesesuaian Kompensasi terhadap Kecenderungan Kecurangan Akuntansi pada Pemerintah Daerah Kabupaten Lombok Timur. InFestasi, 11(1), 41-55.

Arifiyani, H. A., \& Sukirno, S. (2012). Pengaruh Pengendalian Intern, Kepatuhan dan Kompensasi Manajemen terhadap Perilaku Etis Karyawan (Studi Kasus PT Adi Satria Abadi Yogyakarta). Nominal, Barometer Riset Akuntansi dan Manajemen, 1(2), 5-21.

Bpk.go.id, (2018). BPK Ungkap 15.773 Permasalahan Senilai Rp.11,55 Triliun. Dikutip pada 11 April 2019.

Budiarto, D. S., \& Nurmalisa, F. (2018). Hubungan antara Religiusitas dan Machiavellian dengan Tax Evasion: Riset Berdasarkan Perspektif Gender. Telaah Bisnis, 18(1), 19-32.

Faisal, M. (2013). Analisis Fraud di Sektor Pemerintahan Kabupaten Kudus. Accounting Analysis Journal, 2(1), 68-73.

Hafizhah, I., \& Basri, Y. M. (2016). Pengaruh Etika Uang (Money Ethics) terhadap Kecurangan Pajak (Tax Evasion) dengan Religiusitas, Gender, dan Materialisme sebagai Variabel Moderasi (Studi pada WPOP yang Melakukan Kegiatan Usaha atau Pekerjaan Bebas di Pekanbaru). Jurnal Online Mahasiswa (JOM) Bidang Ilmu Ekonomi, 3(1), 1652-1665.

Indriastuti, D. E. (2017). Analisis Pengaruh Asimetri Informasi, Pengendalian Internal, Persepsi Kesesuaian Kompensasi, Moralitas Individu, dan Ketaatan Aturan Akuntansi terhadap Kecurangan Akuntansi. Infestasi, 12(2), 115-130.

Kusumastuti, S., Supatmi, S., \& Sastra, P. (2008). Pengaruh Board Diversity terhadap Nilai Perusahaan dalam Perspektif Corporate Governance. Jurnal Akuntansi dan Keuangan, 9(2), 88-98.

Mustika, D., Hastuti, S., \& Heriningsih, S. (2016). Analisis Faktor-faktor yang Mempengaruhi Kecenderungan Kecurangan (Fraud): Persepsi Pegawai Dinas Kabupaten Way Kanan Lampung. Simposium Nasional Akuntansi XIX. Lampung, 1-22.

Mustikasari, D. P. (2013). Faktor-faktor yang Mempengaruhi Fraud di Sektor Pemerintahan Kabupaten Batang. Accounting Analysis Journal, 2(3), 250-258.

Najah, A. F. (2013). Faktor-faktor yang Mempengaruhi Fraud: Persepsi Pegawai Dinas Provinsi DIY. Accounting Analysis Journal, 2(3), 259-267.

Noviyanti, S. (2008). Skeptisme profesional Auditor dalam Mendeteksi Kecurangan. Jurnal Akuntansi dan Keuangan Indonesia, 5(1), 102-125.

Rachmanta, R., \& Ikhsan, S. (2014). Analisis Faktor-faktor yang Mempengaruhi Kecurangan (Fraud) di Sektor Pendidikan Kota Semarang. Accounting Analysis Journal, 3(3), 387398.

Rizky, M., \& Fitri, F. A. (2017). Pengaruh Keefektifan Pengendalian Internal, Ketaatan Aturan Akuntansi, Penegakan Hukum, dan Perilaku Tidak Etis terhadap Kecurangan Akuntansi. Jurnal Ilmiah Mahasiswa Ekonomi Akuntansi, 2(2), 10-20.

Safitri, D., Hasan, A., \& Fachrunisa, A. (2015). Pengaruh Keefektifan Pengendalian Internal, Keadilan Distributif, Keadilan Prosedural, dan Budaya Etis Organisasi terhadap 


\section{IJBE}

International Journal of Business Economics, 1(1), 38-48, September 2019

http://jurnal.umsu.ac.id/index.php/ijbe

eISSN 2686-472X

Kecenderungan Kecurangan (Fraud) Akuntansi (Studi Empiris pada SKPD Kabupaten Kampar). Jurnal Online Mahasiswa Fakultas Ekonomi Universitas Riau, 2(2), 1-15.

Santoso, U., \& Pambelum, Y. J. (2008). Pengaruh Penerapan Akuntansi Sektor Publik terhadap Akuntabilitas Kinerja Instansi Pemerintah dalam Mencegah Fraud. Jurnal Administrasi Bisnis, 4(1), 14-33.

Singgih, D. W., Yuliati, N. N., \& Amrul, R. (2018). Pengaruh Pengendalian Internal dan Integritas pada Kecenderungan Kecurangan Akuntansi (Studi Kasus pada Dinas SKPD Kota Mataram). Jurnal Aplikasi Akuntansi, 2(1), 42-42.

Tang, T. L.-P., \& Chen, Y.-J. (2008). Intelligence Vs. Wisdom: The Love Of Money, Machiavellianism, and Unethical Behavior Across College Major and Gender. Journal of Business Ethics, 82(1), 1-26.

Tripermata, L. (2016). Pengaruh Love Of Money, Perilaku Etis Mahasiswa dan Komitmen Organisasi terhadap Kecenderungan Kecurangan Akuntansi dengan Gender Sebagai Variabel Pemoderasi. Jurnal Ekonomi Global Masa Kini, 7(1), 55-62.

Tuanakotta, T. M. (2007). Akuntansi Forensik dan Audit Investigatif. Jakarta: Fakultas Ekonomi Universitas Indonesia.

Van Dijk, M. (2000). The Influence of Publication of Financial Statements, Risk of Takeover and Financial Position of The Auditee on Public Auditors' Unethical Behaviour. Journal of Business Ethics, 28(4), 297-305.

Wankhar, A. Z., \& Diana, N. (2018). Pengaruh Money Ethics terhadap Tax Evasion dengan Reliogiousity, Gender, Materialism Sebagai Variabel Moderating (Studi Kasus pada Wajib Pajak Orang Pribadi yang Terdaftar di KPP Pratama Malang Utara). Jurnal Riset Akuntansi, 7(05), 44-58.

Westbrook, K. W., Steven Arendall, C., \& Padelford, W. M. (2011). Gender, Competitiveness, and Unethical Negotiation Strategies. Gender in Management: An International Journal, 26(4), 289-310.

Wilopo, R. (2008). Pengaruh Pengendalian Internal Birokrasi Pemerintah dan Perilaku Tidak Etis Birokrasi terhadap Kecurangan Akuntansi di Pemerintahan: Persepsi Auditor Badan Pemeriksa Keuangan. Ventura, 11(1), 85-100.

Wulandari, S., \& Zaky, A. (2016). Determinan Terjadinya Fraud di Instansi Pemerintahan (Persepsi pada Pegawai BPK RI Perwakilan Provinsi NTB). Jurnal Ilmiah Mahasiswa FEB, 3(2).

Zulkarnain, R. M. (2013). Analisis Faktor yang Mempengaruhi Terjadinya Fraud pada Dinas Kota Surakarta. Accounting Analysis Journal, 2(2), 126-131. 